\title{
Exploring the strategy of government: A statecraft assessment of Angela Merkel's chancellorship from 2005 to 2017
}

\author{
Christian Schnee \\ University of Greenwich, UK
}

\begin{abstract}
As chancellor Angela Merkel is on course to tie with Helmut Kohl as the longest serving democratically elected German head of government, it is time to attempt an initial assessment of the first 12 years of her chancellorship from 2005 to 2017 which left its marks both on German politics and European affairs. Bulpitt's statecraft model is applied to evaluate the chancellor's performance and to judge both achievements and shortcomings of Merkel's incumbency. The theoretical approach chosen provides a scaffolding to direct the research which casts particular attention on four descriptive categories that help condition judgements of a leader's success and failure and take into consideration attitude and behaviour of elites within the system whose actions and degree of allegiance may have advanced or constrained Merkel's leadership. The findings suggest a mixed record that portrays Merkel as an efficient operator whose clout hinged on a firm grip on the CDU (Christian Democratic Union) apparatus and effective management of the parliamentary party. Yet even at the apex of her power, Merkel did not achieve or seek argument hegemony in the public discourse.
\end{abstract}

\section{Keywords}

Angela Merkel, German chancellor, leadership, statecraft

Received: 13th July 2019; Revised version received: XXth MONTH XXXX; Accepted: 9th September 201

\section{Introduction}

Angela Merkel's leadership of the Christian Democrats she succeeded to in 2000 just as her stewardship of the federal government she took over 5 years later has stirred contro-versy and intense debate, which this article seeks to reflect on with a view to assess her performance as chancellor between 2005 and 2017. The literature about Merkel's govern-ments is varied and growing, yet largely of a journalistic kind whose authors all too often 
make no effort in hiding their political sympathies: In her monograph of Merkel, Roll (2009) traces the power games inside the CDU (Christian Democratic Union), while highlighting her subject's determination to climb up the greasy pole and subsequently seek re-election in 2009. For the Spiegel's political editor Kurbjuweit (2009), Merkel early on in her tenure lost a sense of purpose and direction. On a more positive note, Lau - a former political correspondent for the left-leaning daily $T A Z$ - in her monograph applauds the leader for opening the CDU's electorate to more progressive voters (Lau, 2009b). Stark bias too - albeit from another perspective - constitutes the weakness of a volume edited by the journalist Plickert (2017), who draws from academia and journalism an array of 22 outspoken Merkel critics that systematically deconstruct the chancellor's alleged record as level-headed helmsman in difficult times. A trouncing that does not resonate with the inferences about Merkel Kornelius (2013) arrived at in his monograph. As political correspondent, he arguably did not want to sour his relations with the chancellor by dwelling on her shortcomings. Resing (2017) turns to Protestantism as explanatory frame to make sense of Merkel's decisions throughout her first two terms. A thoroughly researched scholarly work is owed to Qvortrup (2016) who particularly casts light on the political latitude Merkel enjoyed as she did not allow her decisions to be restrained by ideological commitments.

The literature about Merkel's chancellorship tests competing frames in rivalling discourses of her performance at the helm of government. The debate is fuelled by a range of academic studies that zoom in on particular aspects of her tenure. Her CDU leadership and repositioning of the party has been explored by Wiliarty (2008, 2013), Clemens (2007, 2009, 2010), Green (2013), Maier (2013), and Turner et al. (2013); foreign policy performance by Mushaben (2009), Gueort (2013), Janes (2014), Wood (2016), and Wendler (2017); her domestic record by Mushaben (2016); the constitutional role of the chancellor and challenges of coalition government by Kropp (2010), Jalalzai (2011), Olsen (2011), and Clemens (2011); the refugee crisis by Mushaben (2017) and Dostal (2017); and her responses to the Eurozone crisis is addressed in a paper by Hertner and Miskimmon (2015). From this brief review, it will appear that the groundwork has been done and it is time to make sense of the current kaleidoscope of perspectives and weave a more coherent narrative of Angela Merkel's performance in office.

The unique contribution to the debate and purpose of this study is to review the available data through the lens of Jim Bulpitt's statecraft model, which has been adopted in a number of academic enquiries (Bevir, 2010; Bradbury, 2010; Bradbury and John, 2010). This article will set out by illustrating the distinct methodological options in leadership assessment and then go on to operationalise the statecraft model for a case study analysis - a step which has been deemed essential as the descriptive categories originally developed by Bulpitt are not fully defined and therefore remain disappointingly vague (Evans, 2006). In the subsequent empirical part of this study, Bulpitt's method will be applied to an assessment of chancellor Merkel's leadership.

\section{Methodology}

Methods applied to assess the performance of political leaders have been varied and usually originate from studies of the US presidency. Arthur Schlesinger (1948) pioneered investigations that relied on expert opinion to rank former leaders according to categories as 'average', 'near great', 'great', or 'failure' (Schlesinger, 1948: 66-67). Since then, studies have asked experts to rate presidents along other more detailed and nuanced scales 
(Pederson and McLaurin, 1987; Schlesinger, 1997). Similarly, in the United Kingdom, the notion of rating and ranking has been popular in comparative studies of prime ministers, yet with a broader focus on personal traits such as leadership skill or their qualities as crisis managers (Theakston and Gill, 2006, 2011).

Lack in clarity and questions about the applicability of similar categories and scales have drawn most criticism (Faber and Faber, 2000). For instance, a category titled 'leadership skill' leaves one wonder what exactly the investigator understands to be skills exercised by a leader. Theakston and Gill (2006) also point out that models emphasising numerical values for distinct categories produce results that rate leaders highly in one respect and dismal in another, which leaves the researcher with a cacophony of scores rather than a coherent aggregate outcome. Hence, Theakston and Gill (2006) demand a model that offers historical context and thus takes nuances into account by evaluating a range of factors which determine political effectiveness as well as governmental outcomes and assist in examining the conditions for success or failure.

It is this approach that informs the fundamentals of the statecraft model which suggests for the assessment of a leader's performance not to hinge on the aggregation of quantifiable expert opinion but on carefully drawn up descriptive categories. Peter Hennessy, for instance, in his exploration of British prime ministers included as evaluative category a leader's ability to bring about change and alter the political climate, since both of which could serve as indicators for successful leadership (Hennessy, 2000). In a similar vein, Fred Greenstein (2009) has developed six features that he draws on to judge the quality of American presidents. He evaluates their capacity as public communicators, looks into their organisational faculties, explores their political skill, assesses their vision of public policy, and critiques their emotional intelligence. The strength of Greenstein's approach is the absence of formal measurement, while the weakness is its failure to engage with the leader's role in producing policy outcomes. Instead, his attention is exclusively dedicated to capacity rather than results. Likewise, Greenstein does not respond to demands to take into account the leader's personality and environmental factors in an assessment as to whether the former is conducive or not to dealing with the latter (Byrne et al., 2017). In light of strengths and weaknesses of past attempts in assessing national leaders, the evaluative framework here chosen is designed by Bulpitt who in the view of Buller and James (2012) is most appreciative of contextual dynamics and institutional as well as political constraints a government faces in a parliamentary system (Bulpitt, 1986). This analytical receptiveness renders it an appropriate prism in the German political context which is defined by constrictions that hem in a head of government: In particular collective leadership, the strong role of political parties vis-à-vis government and the dependency on parliamentary support. A chancellor's operational latitude is further confined by a close-knit clique of senior advisors, influential parliamentary frontbenchers, and prominent members of the party's executive board which all claim a stake in moulding the policy agenda (Helms, 2011).

\section{I}

Bulpitt's model is predominantly concerned both with the process of governing and the outcome. He casts a light on how leaders face challenges and manage the task with a view to improving or at least not endangering their public approval and electoral success (Bulpitt, 1995). Bulpitt applied his model most extensively to an analysis of the premiership of Margaret Thatcher in the 1980s and maintained that her tenure was successful in 
as far as she managed to restore the perception of the Tories as a competent party of government (Bulpitt, 1989, 1996). The analogy to this study's subject of investigation is evident as Angela Merkel achieved a similar about-turn in the CDU's fortune in the wake of major slush fund scandal following electoral defeat in 1998. Bulpitt's theoretical model does further justice to the make-up of the German constitution by recognising the fusion of the executive branch and parliamentary democracy (Bulpitt, 1983, 1995).

Bulpitt's decision to make the winning of elections the main focus and criterion in evaluating the quality of leaders clearly reflects the pressure on British prime ministers and German chancellors alike to produce satisfactory outcomes at the ballot box or face the end of their respective career in national politics. Yet zooming in on election victories exclusively in order to ascertain performance would fall short of capturing the complexities of leaders' profiles and their underlying faculties that are instrumental in securing success. Therefore, Bulpitt developed four descriptive categories for analysis that take note of tasks leaders will have to dispatch effectively in the course of their incumbency in order to maintain and defend their position in power:

\section{A winning electoral strategy}

As the core of the statecraft model is concerned with gaining electoral advantage over adversaries, this criterion demands to reflect the strategies and tactics deployed by leaders to generate traction with the electorate. In the context of this case study, the category can be operationalised by reviewing the trajectory of the polling data in the course of an election campaign in order to recognise if the chancellor's Christian Democrats are able to hold on to or improve their lead or, by contrast, fall behind.

\section{Operational competence in government}

In the view of Bulpitt (1986), governing competence is linked to the shrewd selection and implementation of policies that will lead to electoral success or at least not endanger it. For this goal to be achieved, the chancellor will typically espouse a policy agenda only if it can be seen through successfully. Risky briefs by contrast - and in line with the statecraft model's rationale - she would seek to devolve to other organisations or individuals. In the case of success, the chancellor would still appropriate the praise, in the case of failure timely devolution will spare her the brunt of the flak. This criterion is of particular interest when seen as an extension of Clarke et al.'s (2004) valence model, which suggests that voters seek to support the leader who is associated with competence if the contenders do not differ tangibly on ideology or policy. Perceived competence can be analysed by assessing polling data about the politician's presumed understanding of economic, foreign affairs, and other core issues. These data are best supplemented with qualitative information to illustrate how political protagonists strategically go about creating images and a reputation of administrative competence.

\section{Managing party affairs}

Party management essentially casts a light on the relationship the leader maintains with his or her party (Bulpitt, 1986). However, a political party is a complex entity which consists of local constituencies, regional associations, parliamentary groups in national and state assemblies, and the national executive and organised internal interests 
representing, for instance, employees, the younger members, or small and medium enterprises. The chancellor's rapport with each of those groups does not have to be defined by mutual enthusiasm and wholehearted support, but a reliable state of acquiescence is desirable in order to facilitate collaboration and guarantee the necessary level of backing for the leader's policy choices. In order to operationalise this criterion, the leader's faculties as a party manager are to be assessed by gauging the nature and frequency of internal opposition, particularly in the parliamentary party, as well as efforts made to keep party discipline and restore allegiance.

\section{Hegemony over the political discourse}

Bulpitt (1986) describes hegemony of the argument as the leader's ability to win the political debate and gain broader support for a policy choice or idea. While Bulpitt, however, questions the degree to which hegemony of the argument contributes to electoral success, substantial research infers that the ability to direct the debate, create a public narrative, and frame issues in the media is essential for positive electoral outcomes (Hay, 1996; Phillips, 1998). Public opinion data on key themes in the public discourse could assist in revealing if and to what degree the leader is able to bring about an ideological realignment or refashion a public policy preference. However, this approach implies that the leader publicly advocates identifiable convictions that could be benchmarked against the trajectory of public opinion.

When applying this model to the German context, allowance needs to be made for a tangible difference in political ecosystems: Since the early 1960s, the German electoral system has regularly produced governments whose survival rests on the chancellor's readiness to exercise communicative restraint in order to accommodate the interests and views of vital coalition partners. Thus, one may in particular need to redefine the statecraft model's fourth point by clarifying that a refusal to strive for or establish argument hegemony may actually constitute a political boon and protect the leader's position at the apex of a coalition government. Therefore, in order to do justice to the German chancellor's particular role, the benefit of opting out of the race for argument hegemony would need to be accounted for in the statecraft model's revised category descriptor.

The following paragraphs serve to assess Merkel's chancellorship by applying Bulpitt's adjusted framework to a re-analysis of uncovered literature:

\section{Assessing Merkel's chancellorship I: A winning electoral strategy}

When evaluating the chancellor's performance, it appears essential to remind oneself that in the aftermath of the 2005 election, Merkel was seen as an electoral liability. Her reformist sentiments, calculating neo-liberal rhetoric and the intention to bring about what she called a 'Zweite Republikgründung', a sweeping overhaul of social and economic structures, went so badly down with leery voters that she came within inches of losing a general election the Christian Democrats had been certain to win with a comfortable margin (Hilmer and Hilmer-Müller, 2006). Never has a German political party seen a similarly commanding lead - of up to $25 \%$ in national polls - slip through its fingers in the final weeks of the campaign (Zolleis, 2009). However, the staunchly reformist neo-liberal, antisocial emphasis of the campaign can barely be blamed on the leader (Reiermann, 2005). In 
fact, Zolleis (2008) places the responsibility in part at least at the door of her predecessors and an appetite for an economic reform agenda that had gained the ascendancy in the CDU since the 1990s. In the view of Kurbjuweit, the political near-death experience in the 2005 elections served as a wakeup call for Merkel to disown her party's reformist zeal, reboot her relationship with the electorate, and achieve a symbiosis with the German people (Clemens, 2007; Kurbjuweit, 2009; Niedermayer, 2010). Zolleis (2009) shares this perspective as an explanation for the subsequent political repositioning Merkel engineered in her party: As the CDU/CSU (Christian Social Union) and her preferred partner - the liberal Free Democratic Party (FDP) - for the second time in a decade failed to muster the votes needed to form a coalition, Merkel saw her CDU's pivotal position in German politics at risk unless it embraced a review of policies that would allow her to tap into new electoral segments and become compatible for a wider range of coalition partners (Decker, 2008; Schroeder and Neumann, 2010; Zolleis, 2009). Commentators equate these programmatic changes in response to shifting societal preferences with subsequent buoyant approval ratings for Merkel and her party (Zolleis, 2009), aided by the chancellor's pragmatic nature; considered, steady and logical responses; paired with her shunning of any divisive or scathing public statements and avoidance of party-political swashbuckling (Janes, 2014; Maier, 2013; Olsen, 2011). Her systematic refusal to publicly take a stand and engage in critical political discourse deprived her political adversaries of an opportunity to frame the chancellor as a conservative bogeyman and incite emotions among supporters of the Social Democrats (SPD) and Greens (Blätte, 2009; Von Lucke, 2010). In fact, Merkel's rhetoric style saps all dynamic and controversy from the campaign, thereby lulling her opponents' potential voters into a stupor and readying them to acquiesce to a continuation of her chancellorship (Blätte, 2009; Von Lucke, 2010). She achieves this strategic advantage by claiming the ideological middle ground and marginalising the right wing of her own party on the assumption that disgruntled conservative voters for a lack of alternatives would ultimately stay loyal to the CDU (Kessler and Michels, 2009; Kropp, 2010; Neurer, 2014). For this asymmetrical demobilisation of voters to be a success, her political views have to be notoriously vague - as her critics gripe - or balanced and carefully adapted to popular sentiment and public discourse - as pollsters and campaign strategists acknowledge (Janker, 2017; Streeck, 2016; Ude, 2017). Against this backdrop, it is no mere coincidence that since 2006, Merkel has consistently been more popular than any of her respective Social Democratic challenger and is even judged favourably among voters who do not traditionally support her CDU (Qvortrup, 2016). A somewhat peculiar election result 2009 may serve to vindicate her strategy: On one hand, her party bewailed a fall of its vote share, ending up with 33.8\% which amounted to the worst result since 1949 (Der Bundeswahlleiter, 2009). Yet on the other hand and much more significantly, her main rival, the SPD, suffered from an unprecedented rout as their numbers plummeted by more than 11 to a dismal 23 percentage points which allowed Merkel to hold on to power, this time in a coalition with a re-reinvigorated FDP. Jung et al. (2010) see the 2009 campaign as a direct response to the mistakes made in 2005 and vindication of Merkel's repositioning. Less (2014) recognises how Merkel's unassuming appearance, calm personality, and perceived competence morph into the chancellor's distinctive brand which positively contrasted with the ensuing unwholesome bickering in the ranks of the CDU/CSU-FDP coalition. By 2013, her public image had become imbued with respect that in the words of Less (2014: 50) amounted to a 'cult of personality' which between 2009 and 2013 no other contender for the chancellorship could rival. 
Throughout the 2013 campaign, the CDU emphasised Merkel's role as the guarantor of stability in a sea of international uncertainty and threats - a scenario in part framed by the Eurozone crisis (Decker, 2015). In the months leading up to polling day approval, ratings hovered around $40 \%-43 \%$ and eventually resulted in $41.5 \%$ (Forschungsgruppe Wahlen, 2013), which vindicates the choice of electoral messages that heavily centred on the chancellor's solid record and her apparently confident steering of a growing economy (Clemens, 2018). For Kallnich and Schulz (2015), the 2013 result testifies to the strongest selling point Merkel's team kept emphasising, which her adversaries could not rival: Experience, level-headedness, and competence.

In the 2017 campaign, the Merkel team intended to stick to their guns, avoid controversial pledges, and once more portrayed a vote for the chancellor as an insurance for stability and assured economic prosperity in tumultuous times (Decker and Adorf, 2018; Dostal, 2017). Yet her once stellar personal ratings nosedived in the aftermath of the 2015 refugee crisis the blame for which considerable segments of the electorate - transcending the CDU's notoriously conservative voter base - were quick to place at the chancellor's door. When her party's losses in the 2017 general elections amounted to an unprecedented $8.7 \%$, Angela Merkel's record as a vote winner and effective campaigner is once again called into question. Clemens (2018) blames the dismal showing on a lack of consistency and focus in the campaign which in turn may have its origins in Merkel's diminished authority to assert herself: While she and the majority of CDU officials continued cozying up to progressive left of centre voter base, conservative dissidents in the CDU its associated Bavarian branch CSU openly pivoted towards right wing positions with a view to steal a march on the far-right, anti-immigrant Alternative für Deutschland (AfD). Yet a dismal 20.5\% for the SPD suggests Merkel's recipe for asymmetrical demobilisation of voters did bear fruits once more (Der Bundeswahlleiter, 2017; dpa, 2017). While widely chided for being vacuous and complacent (Clemens, 2018), her party's election manifesto served well by dodging the more ideologically minded attacks from the political left.

\section{Assessing Merkel's chancellorship II: Governing competence}

Arguably, the secret of her stable and smoothly operating first government was Merkel's readiness to meet the SPD's demands more than half way. She wholeheartedly owned up to the constraints of coalition government with a partner of roughly the same size: A need for consensus and an expectation of compromise are two features that chime with the chancellor's natural disposition (Helms, 2011; Jalalzai, 2011; Janes and Szabo, 2007; Olsen, 2011). Merkel, who in the view of Janes and Szabo (2007) had never been associated with ideologically entrenched goals, tended to embrace expediency as her professional organising principle to keep her party in power which required political compatibility with the SPD. Hence she shed the neo-liberal tents her party had adopted at its 2003 convention in Leipzig, plans for tax reform and intended changes to the health system that envisaged the introduction of incentive payments: Strategic decisions which led to a greater programmatic indeterminacy aimed at dressing up the CDU for coalitions with the SPD and - at some point - the Greens (Clemens, 2007; Janes and Szabo, 2007; Zolleis, 2009).

In her role as chancellor, Merkel demonstrated consummate tactical ability by coopting the SPD's policy demands and pre-empting Social Democratic demands for the development of the welfare state, thereby minimising or patching over effectively any 
political and ideological fissure that could otherwise lead to ruptures in the coalition. Most conspicuously during her first term, she allowed the CDU's social wing to demand of SPD federal ministers to loosen the purse-strings for benefits payments to older unemployed workers and sound severe warnings against the SPD's plans to delay retirement age to 67 (Clemens, 2007). While the strategy of outflanking the SPD on the left narrowed any ideological contrast and solidified coalition's cohesion, it indirectly caused Merkel's rival communicative problems as the SPD struggled to define its role, distinguish itself from the CDU, and ultimately explain raison d'etre (Clemens, 2011).

However, it would be overstating Merkel's strategic adroitness if one were to conclude concessions in her two coalitions with the SPD are entirely volitional. Wood (2016) reminds us of the strong constitutional position of cabinet ministers and the intense organisational competition between the chancellery and senior ministerial appointees for leverage over the policy agenda which particularly in the debate about the Greek bailout exacerbated the government's dithering and delay as the chancellor struggled to assert her authority. Against these structural odds and in the midst of macroeconomic challenges, Merkel in her first term managed to steer through a reform of the pension system, preside over a long-awaited disentanglement and streamlining of state and federal legislative procedures, protect public finances in the aftermath of the banking crisis, and earn herself the moniker 'Climate Chancellor', not least for winning over President George W. Bush to her campaign for combatting climate change (Clemens, 2010; Helms, 2011; Mushaben, 2009, 2016).

Initial high hopes for her second government - a coalition with the FDP - were soon dashed: Merkel squandered a golden opportunity when she failed to push through core legislation in the first 6 month while she still commanded a majority in both chambers of parliament (Helms, 2011). Subsequently, the coalition was marred by scathing infighting, bickering between its main protagonists and - a judgement widely voiced among its own supporters - a blatant failure to deliver. Yet Merkel turned a weakness into a strength by extolling the virtue of open debate and a frank scrutiny of ideas. Merkel apparently pursued a twofold strategy: She stayed visibly aloof and distant from infighting to avoid becoming party to debasing conflicts, risking her role as arbiter and damaging her coalition government. At the same time, she uncannily deflected interest and attention from the sorry state of her coalition by focusing minds on foreign policy: In particular, her cautious, tenacious, and seemingly effective management of economic challenges as well as her valiant opposition to the introduction of controversial Eurobonds and other measures mooted by European Union (EU) institutions and members that would have drawn on German financial resources to safeguard the Eurozone in the aftermath of the 2008 crisis (Helms, 2011; Korte, 2010). On aggregate, Merkel's performance on the international stage, her resistance to pleas from prominent voices in the international financial community to demonstrate more financial largesse in her efforts to stave off a currency meltdown, informed among her domestic audience the view of a chancellor who is in control and can be trusted to deal with external threats posed to the country's financial markets and the economic well-being of its people (Guerot, 2013; Korte, 2010).

Zolleis (2009) recognises in Merkel the popular guarantor of administrative competence and political stability, a leader whose longevity in no small part is owed to her flexibility in adjusting policies, her timely adoption of popular and the dropping of less-favoured items from the agenda, and her ability to smooth out the less palatable edges of the Christian Democrat's manifesto (Seils, 2014). Merkel's practice as chancellor and CDU leader is apparently devoid of an ideological drive and a grand vision (Beck, 
2012; Mushaben, 2016). She operates as an ostensibly reasonable helmsperson, who confronts any rabble-rousing provocation with composed analysis and unfailing countenance. In Beck's view, Merkel reflects the mood of the time by appropriating political themes as they crop up and allowing her judgement to be guided by swarm intelligence (Beck, 2012). She refrains from imposing her convictions which makes her so compatible with modern German civic society's demands of a political leader. 'Flying by VFR', ${ }^{1}$ or visual flight, is a term Merkel borrowed from the world of aviation to describe her administrative style and to highlight the need to pause, step back, and recalibrate her course at each step of the way (Alexander, 2013; Helms, 2011; Korte, 2010). This approach allows her to chime with mainstream sentiment which appears to be a contributory factor to her traction with publics and stakeholders that transcend the traditional base of her own party (Caspari, 2013).

Ten years into her tenure, Merkel's image as a competent, hard-headed, both calculating and cautions leader took a most severe hit when in what her detractors called a precipitous decision she agreed on 4 September 2015 to open the border to 20,000 refugees who were trapped in Hungary and keen to seek asylum in Germany. Her critics fret the chancellor's move incentivised unprecedented numbers of asylum seekers to head for Germany, totalling 900,000 thousand by the end of the year. In face of growing public resentment, Merkel refused to budge and sought to allay fears by affirming 'Wir schaffen das' - We'll manage it - (Die Bundesregierung, 2015; Heißler, 2016). In the weeks that followed, Merkel ruled out a cap on migration numbers, brushed aside calls to reintroduce border controls, and exhorted Germans to be welcoming to refugees in need of help (Rinke, 2015). This liberal refugee policy provoked an increasingly hostile backlash among the electorate and contributed to gains for the far right wing party AfD in regional elections which raised questions about Mrs Merkel's grasp of political reality and suggested waning political acumen. Yet, Mushaben (2017) seeks to allay any doubts about the chancellor's administrative competence and political wisdom by recognising in Merkel's insistence on a 'welcoming culture' for refugees the most tangible part of a wider strategy to recruit systematically and in growing numbers migrants to counter a demographic crisis which in Merkel's view the country was ill-prepared to grapple with. Less enthusiastic advocates of Merkel's refugee policy do stress that the chancellor carefully and incrementally adjusted her political course of action in line with a shift of mood in society: When the initial wave of domestic support for the incoming refugees was followed by scepticism, Merkel struck a deal with the Turkish government to manage and reduce the number of new arrivals in the EU and Germany, thus seeking to re-establish her reputation as pragmatic advocate of German interests (Dernbach, 2017).

\section{Assessing Merkel's chancellorship III: Party management}

Following the deeply disappointing election result in 2005, Merkel was quick to clinch a deal with the SPD and secure the CDU's return to power before her internal detractors had time to gain momentum and stage a coup against her (Reutter, 2006; Thompson and Lennartz, 2006). Yet serious misgivings about Merkel's leadership qualities were peddled by senior figures in the party echelon, among them Bavaria's first minister and CSU leader Edmund Stoiber (Vornbäumen, 2005). During her first term in office, a considerable number of Christian Democratic parliamentarians in the Bundestag (national parliament) were just as unwilling to recognise her authority as were the party's regional chieftains whose loyalty could not be taken for granted (Kurbjuweit, 2009). Merkel, who initially lacked a 
supportive network of confidantes in her party (Janes and Szabo, 2007), saw her weakness laid bare when she was forced to back down over internal opposition to her plans for a taxbased reform of health care funding (Rudzio, 2008).

To shore up her position, Merkel sought to appoint trustworthy and loyal stalwarts to her entourage and promote reliable aides in the parliamentary party whose unswerving support she could count on (Schroeder and Neumann, 2010; Schumacher, 2006). Her fight for control over the CDU's parliamentary group had already come to a head in early 2002 when she leaned on its leader, Friedrich Merz, an independent-minded, sharp-witted character, known for his forceful and often acerbic rhetoric, to relinquish his post. In subsequent years, her intra-party rivals failed to join forces to field a challenger as their mutual suspicion thwarted collective action against Merkel (Kurbjuweit, 2009).

Schumacher (2006) reminds us that a party leader's leverage does not hinge on an effective and reliable command structure, but requires other tactical tools: Merkel engineered a loyal following through praises for ambitious and compliant second-tier officials, reprimands for first-tier party rivals, admission for some individuals to her inner circle, cold-shouldering others for signs of defiance. In other words, she offered incentives most aspiring party officials keen to advance their careers are ready to trade their loyalty for (Schumacher, 2006). Regional conferences organised by party headquarters for rank and file members to discuss with the chancellor key policy issues served a similar purpose: These displays of support among loyal party acolytes allowed Merkel to counter disquiet about her course among senior officials (Resing, 2017).

Since 2005, Merkel has systematically rewritten the CDU's ideological tenets and cajoled her party into accepting U-turns on time-honoured policy objectives that failed to curry favour with voters (Kaiser, 2016; Lau, 2008b). Members, officials as well as the parliamentary party were expected to fall in line when their leader in a complete departure from previous statements came round to espouse a minimum wage or ask for military conscription to be discontinued - both decisions were instrumental in Merkel's efforts to expand the CDU's electoral appeal by pandering to left of centre voters (Lau, 2008b; Rothenberg, 2017). Over time, the chancellor's popularity with the electorate reached commanding heights, which rendered her position at the helm unassailable and assured her of unprecedented authority (Clemens, 2011). Soon, the CDU's conservative quarters found themselves in the midst of rear-guard action. Yet they cried foul in vain as Merkel - by now aided by a reliable network of political supporters and a close-knit team of aides in the chancellery and the party headquarters - incrementally reprogrammed the party (Ferree, 2006; Lau, 2009b; Meng, 2008; Mushaben, 2016).

Merkel is seen as the consummate party manager who is sensitive to conflicting internal interests, aware of majorities and adroit in building alliances (Wiliarty, 2008). These acquired leadership skills allowed Merkel to marginalise conservative opponents and invoke the voices of the CDU's social wing in order to poach traditional Social Democratic themes - a strategy she extended beyond the end of the grand coalition and into her subsequent government by the side of the FDP. The latter could not count on Merkel's support as their intense entreaties for health care and social reforms fell on deaf ears among CDU officials (Clemens, 2013). In their 2010 'Berlin Declaration', the party executive explicitly endorsed their leader's course of consensual centrism (Berliner Erklärung, 2010). The document amounted to a formalisation of the party's ongoing repositioning and was certainly helped by the earlier retirement of Merkel's more influential conservative adversaries in particular Merz and Roland Koch, the CDU's former first minister of Hesse (McGroarty, 2010; Neumann, 2008). Merkel's alleged complete 
command over her party in the period investigated here is mirrored in illustrations of the CDU as 'Kanzlerwahlverein', that is, a party devoid of an autonomous political will and needed only to run election campaigns, generate electoral support, and tamely confirm and acclaim the chancellor (Fischer and Wittrock, 2010; Wiliarty, 2013). Yet this perspective of a party that operates merely at the chancellor's behest fails to take into account inbuilt checks and balances in what is a federalist structure, where regional state parliaments and their respective party caucuses, provincial chieftains with influential positions in state and federal cabinet or on the frontbench of parliament, constitute centres of power in their own right that can constrain the chancellor's room to manoeuver. Thus, one could argue that even a strong CDU leader of Merkel's hue, albeit equipped with a bully pulpit to cajole her party to fall in line, appears to operate more like a primus inter pares in a multipolar power system rather than an elected dictator (Murswieck, 1991). Yet Zolleis (2009) qualifies this assertion by pointing out how a shifting power balance has led to unprecedented degrees of centralisation in the CDU whose structural linchpin is the leader. While he concedes that both Kohl in the 1980s and 1990s and Konrad Adenauer in the 1950s and early 1960s were strong-willed and determined characters, he judges Merkel's leverage to direct the party and command discipline to be superior by comparison which in his view is a corollary of the diminished role of regional party leaders and first ministers in shaping policies. This dwarfing of the erstwhile regional powerhouses is a result of the rapid high-speed policy-making processes that are called for by sudden dynamics and erratic changes in the international arena, which require the chancellor and party leader to make immediate decisions at the expense of prior consultation with senior regional party officials. At the same time, the states (Bundesländer) have become ever more dependent financially on federal handouts which tips the power balance even further in Merkel's favour while it erodes the status of regional CDU echelons (Zolleis, 2009).

For Clemens, the ultimate test of Merkel's firm grip on the party came in 2015 and more so in 2016 when senior figures in the hierarchy as well as the rank and file in the regions against their instincts and long-held convictions followed their leader's decision - albeit most grudgingly - to keep open the borders for an hitherto unprecedented influx of refugees (Clemens, 2017). This collective falling in line amounted to a show of strength by the chancellor that was owed to a failure by leading CDU figures to align their tactical objectives and policy goals to a degree needed to advance an alternative to Merkel. In other words, at no time did a dominant coalition hostile to the leader coalesce (Clemens, 2010, 2011). Admittedly, another factor had assisted Merkel by 2015 in attaining an unassailable position in her party: Following regional election defeats, the lines of internal rivals had been thinning as the number of Bundesländer governed by a CDU politician plummeted from 11 in 2010 to a mere 5 in 2015 (Zolleis, 2015).

\section{Assessing Merkel's chancellorship IV: Political argument hegemony}

Angela Merkel appears to place little emphasis on mediatisation and telepolitics as a source of power and administrative leverage (Jacobs, 2010; Qvortrup, 2017). Merkel's communications typically forgoes opportunities to constitute a narrative or raison d'etre of her policies or justify her chancellorship. Korte (2007) recognised strategic value in this reticence and goes on to argue that she is well advised not to act as an overbearing political frontperson who monopolises the public discourse lest her coalition partners' 
sensitivities and government's carefully calibrated power balance get confounded and the administrative cohesion is rendered more precarious as a result of it. In fact, Merkel avoids to be seen as pontificating leader, a role that arguably in another political setting could constitute an effective communicative instrument (Korte, 2007).

Kurbjuweit (2009) makes a similar observation in as much as he struggles to recognise in Merkel's dialogue with the public a systematic choreography, planned images, and persuasive rhetoric to win arguments and sway public discourse. This subdued communicative approach does not allow the chancellor to establish argument hegemony. Rather than fight her corner and forcefully advance her views, she dodges confrontation with rival political parties by poaching and integrating her competitors' policy proposals such as the Green party's demand for an end to nuclear energy usage or the SPD's calls for the introduction of a minimum wage (Medick, 2011; Vates, 2015). In contrast to other northern European centre-right leaders, chancellor Merkel early on abandoned plans to cultivate public support and promote a rationale for a retrenchment of the welfare state her party had demanded in the 2003 Leipzig manifesto (Clemens, 2007). For most of the period investigated, Merkel accepts by default the existing argument hegemony and eschews public commitment to one controversial cause or another (Grasselt and Korte, 2007; Müller, 2009; Olsen, 2011). Instead she engages in tactical breaks, days of public non-communication, while she waits for the public discourse to develop and only positions herself when a dominant current crystallises (Mushaben, 2016; Olsen, 2011). The outcome she declares as 'alternativlos' (without alternative) in an expectation that imperative terminology may spare her subsequent public controversy (Kurbjuweit, 2014).

Merkel's hesitant public leadership in foreign policy confirms Beck's (2012), Korte's (2007), and Maier's (2013) characterisation of her communicative style: The chancellor has been known for her reticence and reluctance to nail her colour to the mast when unpopular decisions are on the agenda. In response to France's, the United Kingdom's, and the United States' request of German support for the NATO operation 2011 in Libya, chancellor Merkel showed little inclination to challenge public sentiment in Germany which at the time was hostile to military intervention (Horeld, 2011). Subsequently, Merkel called for participation of German forces alongside French troops in military action in Mali and the Central African Republic as both main parties in the Bundestag were in favour of the commitment in line with public opinion led by positive journalistic coverage (YouGov, 2013). In a similar vein, in order to minimise controversy and opposition to her EU agenda, she carefully floated and skipped in between and across the lines of Eurosceptics and Europhiles without attempting to lend her public support to either group (Busse, 2011). While economists pleaded for financial largesse in helping the southern European states during the EU currency crisis, Merkel advocated fiscal austerity measures in recipient countries as condition for financial transfers. Her stance was interpreted as a nod to a large segment of her voter base that showed only limited sympathy for prolonged generosity towards Greece and other debtors (Crawford and Czuczka, 2013; Fischer, 2011).

Her attempts at establishing argument hegemony remain few and far between: In the early years of her tenure, high-profile summits on energy policy were convoked in April and October 2006 and again in July 2007 intended to assist Merkel in pre-empting communications on the subject by her coalition partner and parliamentary opposition (Glaab, 2010). The decision to have Merkel embark on a well-advertised trip to Greenland in 2007 also served to reclaim the agenda and push the chancellor's rivals onto the back foot in the discourse over policy options to counter climate change. Thus, Merkel's early 
sobriquet as 'climate chancellor' was an example - albeit a rare one - of her success in dominating the agenda (Glaab, 2010).

One might argue that Merkel's most conspicuous endeavour to publicly advocate a policy preference by challenging critics and a wary populace came to pass in 2015 when Germany suspended the EU's Dublin Regulation and welcomed an unprecedented number of refugees. While initially buoyed by a groundswell of goodwill, before long, Merkel's policy faced a vocal outburst of anger among the electorate which resulted in dramatically plummeting personal poll ratings (Forschungsgruppe Wahlen, 2016; Schick, 2016). As the chancellor for once sought to weather a hostile public and follow through a policy she professed to believe in by arguing against demands for a cap on refugee numbers, her Christian Democrats' approval ratings started sliding and before long earlier hopes of gaining an absolute majority of the popular vote in the following federal elections appeared illusionary (Forschungsgruppe Wahlen, 2015). In response during 2016, Merkel conceded to tighten migration and asylum legislation, deport refugees to their home countries, and declare a range of states safe havens whose citizens could not expect to be granted asylum in Germany (Stalinski, 2017). While these policy adjustments did not amount to an explicit U-turn, they once more confirmed how Merkel is instinctively inclined to accommodate public opposition and play to the gallery of the electorate rather than engage with a critical populace in an attempt to challenge and overcome an adverse mood. Therefore, on balance, establishing argument hegemony has not been Merkel's ultimate endeavour on this occasion either.

\section{Conclusion}

To what degree the analysis of purposive realist behaviour can be anchored in conclusive evidence has been the subject of contention. Admittedly, the investigative process and the inferences made are contingent on the plausibility of the arguments, which in the context of this study are grounded in comprehensive discovered data. Against this background, the view has been taken here, that applying Bulpitt's model is a theoretically rigorous way of analysing Merkel's chancellorship. The findings will now be briefly summarised:

The bottom line in the assessment of a leader's statecraft is the ability to gain and retain office. This is therefore the criterion to be applied to any evaluation of performance and success. Bearing in mind this benchmark, the most notable leadership quality is arguably Angela Merkel's substantial learning curve since 2005. In other words, the German chancellor has revealed herself to be a learning system that scans the environment, shows awareness of stakeholders, and responds to the political eco-system pragmatically. Mistakes made in the 2005 election campaign were not repeated, messages and policies henceforth calibrated to fit the mood and expectations of a broadened electoral base.

Key to Merkel's longevity in office is the firm grip she established on her party with a view to push and tug its course in line with two basic requirements: First of all, the programmatic needs of the coalition governments she forged and tried to steer consensually. And second, her political positioning and electoral approach aimed at demobilising the SPD's voter base by eschewing conspicuously conservative or neo-liberal stances. Another observation fits into this stratagem: The avoidance of opinion hegemony. Any attempts to lead from the front and put her weight behind controversial policies with a view to mould public perception and shape majority views may have ruptured the finely balanced relationship between coalition partners and spawned internal acrimony that ultimately could have risked the chancellor's power base. Also, the German electorate 
appeared to have no appetite for a reformist leader and showed instead sympathy for a guarantor of stability, predictability, and reassurance which Merkel chose to offer against a disconcerting political and economic backdrop in the EU and the wider world. Her authority as party leader and chancellor rests on the integration of her public persona as an analytical, reliable, and level-headed political manager with her reputation as anchor of stability who can be trusted to navigate the vicissitudes of a dynamic international arena. The underlying theme that assists in understanding the longevity of her chancellorship is arguably her readiness to be pragmatic, allow for contingencies, and be responsive to stakeholder demands - three requirements that define a learning system and explain chancellor Merkel's ability to ride the crest of the wave for a longer time than most of her predecessors. That is hardest evidence of her success.

\section{Funding}

The author(s) received no financial support for the research, authorship, and/or publication of this article.

\section{References}

Alexander R (2013) Sie steuert auf Sicht und wechselt im Notfall den Kurs. Die Welt, 31 March. Available at: https:/www.welt.de/print/wams/debatte/article114898917/Sie-steuert-auf-Sicht-und-wechselt-im-Notfall -den-Kurs.html (accessed 14 June 2017).

Beck U (2012) Merkiavellis Macht. Das Zögern der Kanzlerin bei der Euro-Rettung. Spiegel Online, 8 October. Available at: http://www.spiegel.de/spiegel/print/d-88963881.html (accessed 20 June 2017).

Berliner Erklärung (2010) Unsere Perspektive 2010-2013, 15 January. Christlich Demokratische Union (CDU). Available at: https://www.cdu.de/artikel/berliner-erklaerung-unsere-perspektiven-2010-2013 (accessed 10 June 2019).

Bevir M (2010) Interpreting territory and power. Government and Opposition 45(3): 436-456.

Blätte A (2009) Reduzierter Parteienwettbewerb durch kalkulierte Demobilisierung. In: Korte KR (ed.) Die Bundestagswahl 2009. Berlin: Springer, pp.273-297.

Bradbury J (2010) Jim Bulpitt's territory and power in the United Kingdom and interpreting political development: Bringing state and temporal analysis back in. Government and Opposition 45(3): 318-344.

Bradbury J and John P (2010) Territory and power: Critiques and reassessments of a classic work. Government and Opposition 45(3): 295-317.

Buller J and James TS (2012) Statecraft and the assessment of national political leaders: The case of New Labour and Tony Blair. The British Journal of Politics and International Relations 14(4): 534-555.

Bulpitt J (1983) Territory and Power in the United Kingdom. Manchester: Manchester University Press.

Bulpitt J (1986) The discipline of the New Democracy: Mrs Thatcher's Domestic statecraft. Political Studies 34(1): 19-39.

Bulpitt J (1989) Walking back to happiness? Conservative party government and elected local authorities in the 1980s. In:Crouch C and Marquand D (eds) The New Centralism: Britain Out of Step in Europe? Oxford: Blackwell, pp.56-73.

Bulpitt J (1995) Historical politics: macro, in-time, governing regime analysis. In: Lovenduski J and Stanyer J (eds) Contemporary Political Studies, vol. 2. Belfast: Political Studies Association, pp.510-520.

Bulpitt J (1996) Historical politics: Leaders, statecraft and regime in Britain at the accession of Elizabeth II. In: Hampster-Monk I and Stayner J (eds) Contemporary Political Studies, vol. 2. Oxford: Blackwell, pp.1093-1106. 
Busse N (2011) Angela Merkel und die Euro-Krise: Die Eiserne Kanzlerin laviert. Frankfurter Allgemeine, 20 July. Available at: http://www.faz.net/aktuell/wirtschaft/eurokrise/angela-merkel-und-die-euro-krise-die -eiserne-kanzlerin-laviert-11115175.html (accessed 5 May 2017).

Byrne C, Randall N and Theakston K (2017) Evaluating British prime ministerial performance: David Camerons premiership in political time. British Journal of Politics and International Relations. 19(1): 202-220.

Caspari L (2013) Grünen-Wähler mögen Merkel. Zeit Online, 22 February. Available at: http://www.zeit.de /politik/deutschland/2013-02/gruene-merkel-sympathie-schwarz-gruen (accessed 2 August 2017).

Clarke HD, Sanders D, Stewart MC and Whitley P (2004) Political Choice in Britain. Oxford: Oxford University Press.

Clemens C (2007) Two steps forward, one step back: Merkel's CDU/CSU and the politics of welfare state reform. German Politics 16(2): 226-246.

Clemens C (2009) Modernisation or disorientation? Policy change in Merkel's CDU. German Politics 18(2): 121-139.

Clemens C (2010) Lose-lose proposition: Policy change and party politics in the grand coalition. German Politics and Society 28(3): 1-24.

Clemens C (2011) Explaining Merkel's autonomy in the grand coalition: Personalisation or party organisation? German Politics 20(4): 469-485.

Clemens C (2013) Beyond Christian Democracy? Welfare state politics and policy in a changing CDU. German Politics 22(1-2): 191-211.

Clemens C (2017) The CDU/CSU's ambivalent 2017 campaign. In: Langenbacher E (ed.) The Twilight of the Merkel Era. New York: Berghahn Books.

Clemens C (2018) The CDU's ambivalent 2017 campaign. German Politics and Society 36(2): 55-75.

Crawford A and Czuczka T (2013) Angela Merkel. A Chancellorship Forged in Crisis. New York: Bloomberg Press.

Decker F (2008) Wo wir sind, ist die Mitte. Zum Standort der CDU im deutchen Pateienystem. Neue Gesellschaft/Frankfurter Hefte 55 (1-2): 12-15.

Decker F (2015) Zur Entwicklung des bundesdeutschen Parteiensystems vor und nach der Bunstagswahl 2013. Überwinung der koalitionspolitischen Segmentierung. In: Korte KR (ed.) Die Bundestagswahl 2013: Analysen Der Wahl-, Parteien-, Kommunikations- Und Regierungsforschung. Heidelberg: Springer VS, pp 143-164.

Decker F and Adorf P (2018) Coalition politics in crisis? The German party system before and after the 2017 federal elections. German Politics and Society 36(2): 5-26.

Der Bundeswahlleiter (2009) Die Bundestagswahl 2009. Available at: https://www.bundeswahlleiter.de/bunde stagswahlen/2009.html (accessed 4 August 2017).

Der Bundeswahlleiter (2017) Die Bundestagswahl 2017. Available at: https://www.bundeswahlleiter.de/bunde stagswahlen/2017/ergebnisse.html

Dernbach A (2017) 280.000, Asylsuchende - Flüchtlingszahl sinkt um zwei Drittel. Der Tagesspiegel, 11 January. Available at: https://www.tagesspiegel.de/politik/fluechtlinge-280-000-asylsuchende-fluechtling szahl-sinkt-um-zwei-drittel/19238258.html (accessed 20 June 2017).

Die Bundesregierung (2015). Sommerpressekonferenz von Bundeskanzlerin Merkel, 31 August. Available at: https://www.bundesregierung.de/breg-de/aktuelles/pressekonferenzen/sommerpressekonferenz-vonbundeskanzlerin-merkel-848300 (accessed 5 August 2017).

Dostal J (2017) The German federal elections of 2017: How the wedge issue of refugees and migration took the shine off chancellor Merkel and transformed the party system. The Political Quarterly 88(4): 589-602.

dpa (2017) CDU und SPD verlieren, AfD drittstärkste Kraft. Wirtschaftswoche, 22 September. Available at: http://www.wiwo.de/politik/deutschland/bundestagswahl-2017/letzte-umfragen-vor-der-wahl-cdu-und -spd-verlieren-afd-drittstaerkste-kraft/20366870.html (accessed 23 September 2017).

Evans M (2006) Elitism. In: Hay C, Lister M and Marsch D (eds) The State: Theories and Issues. Basingstoke: Palgrave Macmillan, pp.39-58.

Faber C and Faber R (2000) The American Presidents Ranked by Performance. Jefferson, NC: McFarland.

Ferree M (2006) Angela Merkel: What does it mean to run as a woman? German Politics and Society 24(1): 93-107.

Fischer S (2011) Merkels Europa-Politik: Sprachlos, ziellos, mutlos. Spiegel Online, 17 July. Available at: http://www.spiegel.de/politik/deutschland/merkels-europa-politik-sprachlos-ziellos-mutlos-a-774925 .html (accessed 15 May 2017).

Fischer S and Wittrock P (2010) Merkel bastelt sich ihren Kanzlerwahlverein. Spiegel Online, 14 November. Available at: http://www.spiegel.de/politik/deutschland/die-neue-cdu-merkel-bastelt-sich-ihren-kan zlerwahlverein-a-727979.html (accessed 4 May 2017).

Forschungsgruppe Wahlen (2013) ZDF Politbarometer. Available at: https://www.wahlrecht.de/umfragen/ politbarometer/politbarometer-2013.htm. (accessed 6 October 2019). 
Forschungsgruppe Wahlen (2015) ZDF Politbarometer. Available at: http://www.forschungsgruppe.de /Umfragen/Politbarometer/Archiv/Politbarometer_2015/November_II_2015/ (accessed 5 July 2017).

Forschungsgruppe Wahlen (2016) ZDF Politbarometer. Available at: http://www.forschungsgruppe.de /Umfragen/Politbarometer/Archiv/Politbarometer_2016/Januar_I_2016/ (accessed 7 July 2017).

Gast H and Kranenpohl U (2008) Große Koalition - schwacher Bundestag. Aus Politik Und Zeitgeschichte 16: $18-23$.

Glaab M (2010) Political leadership in der Großen Koalition. Führungsressourcen und Stile von Bundeskanzlerin Merkel. In: Egle C and Zohlnhöfer R (eds) Die Zweite Große Koalition: Eine Bilanz der Regierung Merkel 2005-2009. Berlin: Springer, pp.123-155.

Grasselt N and Korte KR (2007) Führung in Politik und Wirtschaft. Instrumente, Stile und Techniken. Wiesbaden: VS Verlag für Sozialwissenschaften.

Green S (2013) Societal transformation and programmatic change in the CDU. German Politics 22(1-2): 46-63.

Greenstein FI (2009) The Presidential Difference: Leadership Style from FDR to Barack Obama. Princeton, NJ: Princeton University Press.

Guerot U (2013) Merkel's European and foreign policy legacy on the eve of the German elections: European hegemon or global player? The Polish Quarterly of International Affairs 22(2): 11-27.

Hay C (1996) Re-stating Social and Political Change. Buckingham: Open University Press.

Heißler J (2016) Merkels drei große kleine Worte. Tagesschau.de, 31 August. Available at: https://www.tagesschau .de/inland/merkel-wir-schaffen-das-101.html (accessed 18 June 2017).

Helms L (2011) Angela Merkel and the unfulfilled promise of chancellor democracy. Current History 110(734): 97-102.

Hennessy P (2000) The Prime Minister: The Office and Its Holders since 1945. London: Penguin.

Hertner I and Miskimmon A (2015) Germany's strategic narrative of the Eurozone crisis. German Politics and Society 33(1-2): 42-57.

Hilmer R and Hilmer-Müller R (2006) Die Bundestagswahl vom 18. September 2005: Votum für Wechsel in Kontinuität. Zeitschrift für Parlamentsfragen 37(1): 183-218.

Horeld M (2011) Deutschlands feige Außenpolitik. Zeit Online, 18 March. Available at: http://www.zeit.de /politik/deutschland/2011-03/libyen-sicherheitsrat-westerwelle (accessed 14 June 2017).

Jacobs HJ (2010) Kanzlerin als Führungskraft. Kommunikation. Süddeutsche Zeitung, 14 June. Available at: http://www.sueddeutsche.de/politik/kanzlerin-als-fuehrungskraft-merkels-mankos-1.957430-5 (accessed 13 August 2017).

Jalalzai F (2011) A critical departure for women executives or more of the same - The powers of chancellor Merkel. German Politics 20(3): 428-448.

Janes J (2014) German foreign policy in the aftermath of the 2013 Bundestag election. German Politics and Society 32(3): 86-97.

Janes J and Szabo S (2007) Angela Merkel's Germany. Current History 106(698): 106-111.

Janker K (2017) Interview with Thea Dorn in Süddeutsche Zeitung Online, 5 July. Available at: http://www .sueddeutsche.de/politik/wahl-watcher-thea-dorn-merkel-laesst-sich-von-meinungsumfragen-die-politik -diktieren-1.3572934 (accessed 22 August 2017).

Jung M, Schroth Y and Wolf A (2010) Wähleverhalten und Wahlergebnis, Regiungswechsel ohne Wechelstimmung. In: Korte KR (ed.) Die Bundestagwahl 2009: Analysen der Wahl-, Parteien-, Kommunikations- und Regierungsforschung. Heidelberg: Springer VS, pp.35-47.

Kaiser T (2016) Die ökonomische Elite blitzt bei Merkel völlig ab. Die Welt, 2 November. Available at: https:// www.welt.de/wirtschaft/article159222231/Die-oekonomische-Elite-blitzt-bei-Merkel-voellig-ab.html (accessed 25 August 2017).

Kallnich D and Schulz F (2015) Eine Regierungsbilanz der schwarz-gelben Koalition 2009 - 2013: Erklärungsarmer Pragmatismus. In: Korte KR (ed.) Die Bundestagswahl 2009: Analysen der Wahl-, Parteien-, Kommunikationsund Regierungsforschung. Heidelberg: Springer VS, pp.431-456.

Kessler M and Michels R (2009) Warum die Union mit Merkel fremdelt. RP Online, 10 March. Available at: http://www.rp-online.de/politik/deutschland/warum-die-union-mit-merkel-fremdelt-aid-1.2300538 (accessed 21 August 2017).

Kornelius S (2013) Angela Merkel: The Authorized Biography. London: Alma Books.

Korte KR (2007) Koalition der Willigen: Warum die Bundesregierung ihr Potential nicht ausschöpft. Internationale Politik 2(2): 90-91.

Korte KR (2010) Präsidentielles Zaudern Der Regierungsstil von Angela Merkel in der Großen Koalition 2005-2009. In: Bukow S and Seemann W (eds) Die große Koalition. Wiesbaden: VS Verlag für Sozialwissenschaften. pp.102-122. 
Kropp S (2010) The ubiquity and strategic complexity of grand coalition in the German federal system. German Politics 19(3-4): 286-311.

Kurbjuweit D (2009) Die Kanzlerin Für Alle. München: Carl Hanser.

Kurbjuweit D (2014) Alternativlos: Merkel, die Deutschen und das Ende der Politik. München: Carl Hanser.

Lau M (2009b) Die letzte Volkspartei: Angela Merkel und die Modernisierung der CDU. München: DVA.

Less C (2014) Chancellor hegemony, party politics and the Bundestag party system after the 2013 federal elections. German Politics and Society 32(2): 41-53.

McGroarty P (2010) Party ally - and potential rival - of Merkel plans to resign. The Wall Street Journal, 26 May. Available at: https://www.wsj.com/articles/SB10001424052748704026204575266024144634784 (accessed 15 April 2017).

Maier C (2013) Crisis? What crisis? The state of German conservatism. Renewal 20(4): 30-34.

Medick V (2011) CDU-Wende beim Mindestlohn: Genossin Merkel. Der Spiegel, 30 October. Available at: http://www.spiegel.de/politik/deutschland/cdu-wende-beim-mindestlohn-genossin-merkel-a-794844 .html (accessed 7 July 2017).

Meng R (2008) Das Bündnis der Artgleichen: Eine krtische Zwischenbilanz der Großen Koaltion aus journalistischer Sicht. In: Tenscher J and Batt H (eds) 100 Tage Schonfrist: Bundespolitik und Landtagswahleni im Schatten der Großen Koaliton. Wiesbaden: VS Verlag für Sozialwissenschaften, pp.283-294.

Müller D (2009) Interview with Gero Neugebauer in Deutschlandfunk, 3 March. Available at: http://www .deutschlandfunk.de/frau-merkel-wartet-frau-merkel-zoegert.694.de.html?dram:article_id=66890 (accessed 1 June 2017).

Murswieck A (1991) Führungsstile in der Politik in vergleichender Perspektive. In: Hartwich HH and Wewer G (eds) Regieren in der Bundesrepublik II. Wiesbaden: Springer Fachmedien, pp.81-96.

Mushaben J (2009) Madam Chancellor: Angela Merkel and the triangulation of German foreign policy. Georgetown Journal of International Affairs 10(1): 27-35.

Mushaben J (2016) The best of times, the worst of times: Angela Merkel, the grand coalition, and majority rule in Germany. German Politics and Society 34(1): 1-25.

Mushaben J (2017) Wir schaffen das! Angela Merkel and the European refugee crisis. German Politics 26(4): 516-533.

Neumann P (2008) Der Geheimbund der CDU-Männer ist am Ende. Die Welt, 1 February. Available at: https:// www.welt.de/politik/article1623266/Der-Geheimbund-der-CDU-Maenner-ist-am-Ende.html (accessed 17 June 2017).

Niedermayer O (2010) Parteien und Parteiensystem. In: Bukow S and Seemann W (eds) Die Große Koalition: Regierung, Politik, Parteien, 2005-2009. Heidelberg: Springer VS, pp.247-261.

Olsen J (2011) Leadership in grand coalitions: Comparing Angela Merkel and Kurt Georg Kiesinger. German Politics 20(3): 342-359.

Pederson WD and McLaurin AM (1987) The Rating Game in American Politics. New York: Irving Publisher.

Phillips L (1998) Hegemony and political discourse: The lasting impact of Thatcherism. Sociology 32(4): 847-867.

Plickert P (2017) Merkel: Eine Kritische Bilanz. München: FinanzBuch Verlag.

Qvortrup M (2016) Angela Merkel: Europe's Most Influential Leader. New York: The Overlook Press.

Reiermann C (2015) Charme and Chance der Verlegenheitslösung. Die Welt, 2 October. Available at: https:// amp.welt.de/print-wams/article132920/Charme-und-Chance-der-Verlegenheitsloesung.html (accessed 20 May 2019).

Resing V (2017) Angela Merkel - Die Protestantin: Ein Porträt. Freiburg im Breisgau: Verlag Herder.

Reutter W (2006) Who is afraid of Angela Merkel? The life, political career, and future of the new German Chancellor. International Journal 61(1): 214-226.

Rinke A (2015) 'Dann ist das nicht mein Land' - Merkels Vertrauensfrage. Reuters, 15 September. Available at: http://de.reuters.com/article/fl-chtlinge-deutschland-merkel-idDEKCN0RF1S920150915 (accessed 18 June 2017).

Roll E (2009) Die Kanzlerin: Angela Merkel's Weg Zur Macht. Berlin: Ullstein Taschenbuch.

Rothenberg C (2017) Interview with Erika Steinbach on NTV, 16 January. Available at: http://www.n-tv.de /politik/Merkel-ist-egal-was-ihre-Partei-will-article19562756.html (accessed 18 August 2017).

Rudzio W (2008) Informelles Regieren: Das Koaltionsmanagement der Regierung Merkel. Aus Politik Und Zeitgeschehen 58(16): 11-17.

Schick N (2016) Angela Merkel's open door has left her fighting for survival. The Telegraph, 23 July. Available at: http://www.telegraph.co.uk/opinion/2016/07/23/angela-merkels-open-door-has-left-her-fighting-for -survival/ (accessed 22 June 2017). 
Schlesinger AM Jr (1948) The US presidents: What makes a president great, average or a failure? The verdict of history provides some answers. Life Magazine 112(2): 65-74.

Schlesinger AM Jr (1997) Rating the presidents: Washington to Clinton. Political Science Quarterly 112(2): 179-190.

Schroeder W and Neumann A (2010) Die CDU in der Großen Koalition auf dem Weg zu einer neuen strategischen Zeitgenossenschaft. In: Bukow S and Seemann W (eds) Die Große Koalition 2005 to 2009. Wiesbaden: Verlag für Sozialwissenschaften.

Schumacher H (2006) Machtphysik. Berlin: Helios Media.

Seils C (2014) Angela Merkel und ihr Wahlverein. Der Tagesspiegel, 23 June. Available at: http://www .tagesspiegel.de/meinung/andere-meinung/cdu-will-sich-reformieren-angela-merkel-und-ihr-wahlverein /10087946.html (accessed 14 August 2017).

Stalinski S (2017) Die Meisterin der Anpassung. Tagesschau.de, 22 February. Available at: https://www.tagesschau .de/inland/merkel-fluechtlingspolitik-113.html (accessed 22 June 2017).

Streeck W (2016) Merkels neue Kleider. Frankfurter Allgemeine Zeitung, 3 May. Available at: http://www.faz .net/aktuell/feuilleton/debatten/regierungsstil-merkels-neue-kleider-14212048.html (accessed 20 August 2017).

Theakston K and Gill M (2006) Ranking 20th century British prime ministers. British Journal of Politics and International Relations 8(2): 193-213.

Theakston K and Gill M (2011) The post-war premiership league. The Political Quarterly 82(1): 67-80.

Thompson M and Lennartz L (2006) The making of chancellor Merkel. German Politics 15(1): 99-110.

Turner E, Green S and Paterson W (2013) Introduction: Understanding the transformation of the CDU. German Politics 22(1-2): 1-15.

Ude C (2017) Die Alternative Oder: Macht Endlich Politik. München: Knaus.

Vates D (2015) 10 Jahre Angela Merkel: Eine Bundeskanzlerin, die Konfrontation vermeidet. Kölner Stadtanzeiger, 20 November. Available at: http://www.ksta.de/politik/-zehn-jahre-merkel-sote-immer-fuer -eine-ueberraschung-gut-23314452 (accessed 2 August 2017).

Von Lucke A (2010) Zehn Jahre Merkel und das Dilemma der CDU. Blätter für deutsche und internationale Politik (4): 5-8.

Vornbäumen A (2005) Stoibers Misstrauensvotum. Der Tagesspiegel, 2 November. Available at: http://www .tagesspiegel.de/meinung/stoibers-misstrauensvotum-von-axel-vornbaeumen/655860.html (accessed 22 August 2017).

Wendler F (2017) Recalibrating Germany's role in Europe: Framing leadership as responsibility. German Politics 26(4): 574-590.

Wiliarty S (2008) Angela Merkel's path to power: The role of internal party dynamics and leadership. German Politics 17(1): 81-96.

Wiliarty S (2013) Gender as a modernising force in the German CDU. German Politics 22(1-2): 172-190.

Wood L (2016) The bureaucratic politics of Germany's first Greek bailout package. German Politics and Society 34(1): 26-53.

YouGov (2013) Transall-Einsatz für Mali beginnt. Jeder zweite Deutsche dafür. Zeit Online, 17 January. Available at: https:/www.zeit.de/news/2013-01/17/konflikte-bundeswehr-beginnt-mali-einsatz-transallgestartet-17201006 (accessed 19 August 2017).

Zolleis U (2008) Die CDU - Das politische Leitbild im Wandel der Zeit. Heidelberg: Springer VS.

Zolleis U (2009) Indeterminacy in the political center ground: Perspectives for the Christian Democratic Party. German Politics and Society 27(2): 28-44.

Zolleis U (2015) Auf die Kanzlerin kommt es an. Die CDU unter Angela Merkel. In: Zohlnhöfer R and Saalfeld T (eds) Politik im Schatten der Krise: Eine Bilanz der Regierung Merkel 2009 to 2013. Wiesbaden: Springer Fachmedien. pp.73-91.

\section{Author biography}

Christian Schnee served as campaign manager for Germany's Christian Democratic Party and special advisor to the First Minister of Hamburg before returning to academia. Since 2015, he teaches at the University of Greenwich in London and writes about European politics and political history. He is author of the monograph Political Reputation Management: The Strategy Myth (Routledge, 2015) and the first German language biogra-phy on King George I (Ludwig Verlag, 2013). His articles have been published in Contemporary Politics, German Politics \& Society, Journal of Management History, Journal of Management and Organisational History, and Corporate Reputation Review. 